\title{
ANALYSIS OF FILTRATION PROCESSES BY EARTH HYDROTECHNICAL STRUCTURES
}

\author{
Andrzej Tadeusz Gruchot, Tymoteusz Zydroń, Eugeniusz Zawisza, Damian Bembenek, \\ Łukasz Szałucha
}

Department of Hydraulic Engineering and Geotechnics, Faculty of Environmental Engineering and Land Surveying, The Agricultural University of Kraków, Al. Mickiewicza 24/28, 30-059 Kraków

\begin{abstract}
Aim of the study

The paper presents calculations of filtration through a side dam of the "Maziarnia" water reservoir in Wilcza Wola in the Podkarpackie Voivodeship.

Material and methods

In the selected sections, on the basis of penetration drilling and research excavations, the geotechnical structure of the dam body and base was identified and samples for laboratory tests were taken. The results of the tests and calculations of the soil filtration coefficient of the dam body were used for the calculation of unsteady and steady filtration through the dam using the finite element method in the GEO5 software.
\end{abstract}

\section{Results and conclusions}

The analysis of the results showed differences in the filtration coefficient values obtained from laboratory tests and calculated using empirical formulas as well as a relatively good compatibility of the position of computational filtration curve through the dam with the curve resulting from piezometric measurements.

Keywords: finite element method, earth-fill dam, coefficient of permeability

\section{INTRODUCTION}

Earth hydrotechnical structures are large cubature objects, built from native soil, rubble, and also rock debris (Depczyński and Szamowski, 1999). Water piling is a specific feature of such structures that renders the object and its foundation affected by the phenomenon of water filtration. This phenomenon occurs when water fills the pore spaces in soil and travels inside them due to gravity or differential pressure (Wiłun, 2001). Phenomena provoked by water filtration (mechanical and chemical suffosion, hydraulic perforation, displacement) can cause damage to a hydrotechnical structure due to internal erosion or filter and drainage colmatation. In addition to filtration, the condition of hydraulic structures are also affected by contact with surface water, which may lead to smudges, abrasion, cavitation damages or silting of - for example - drainages (Kledyński, 2011).

An inspection of the condition of earth hydrotechnical structures includes observations, as part of periodic surveys, deflection measurement (mainly, of settlements), piezometric levels of filtration water in the body and groundwater in the foundation as well as filtration output. The scope of this inspection can be supplemented with field and laboratory geotechnical investigations of land and dynamic or static sounding (Borys and Mosiej, 2005; Kledyński, 2011).

区e-mail: rmgrucho@cyf-kr.edu.pl 
Filtration conditions in earth hydrotechnical structures need to be determined to ensure their safety. Therefore, one of the main problems concerning control of these facilities lies in proper identification of phenomena related to water filtration and the possibility of their occurrence (Borys, 2007; Chalfen et al., 2008; Zawisza and Klimek, 2016). The necessity of conducting technical and safety inspections of hydrotechnical structures follows, i.a., The Construction Law Act (Dz.U. 1994 r. Nr 89, poz. 414) and regulations, in particular The Regulation of the Ministry of the Environment regarding technical conditions for hydrotechnical structures and their location (Dz.U. z 2007 r. Nr 86, poz. 579).

The aim of the research was geotechnical exploration of soils that build the body of the lateral dam "B" of the water reservoir 'Maziarnia' in Wilcza Wola in the Podkarpackie Voivodeship. The position of filtration curve was also determined on the basis of filtration calculations carried out using the finite element method. The results of the calculations were referred to the measurements of the water table height in piezometers.

\section{TECHNICAL CHARACTERISTICS OF THE RESERVOIR}

The 'Maziarnia' water reservoir in Wilcza Wola is located on the Łeg River, a right-bank tributary of the Vistula. The dam of the reservoir was built on the $56.1 \mathrm{~km}$ of the river, closing the subcatchment with an area of $233.0 \mathrm{~km}^{2}$. The Łęg River catchment belongs to the Kolbuszowski Plateau and the Rozwadowska
Plain, situated within the Sandomierz Basin. Peat bogs and wetlands can be found at many sites of the lowland, especially in its lowest parts (Tarnawski and Michalec, 2006).

The reservoir was put into operation in 1989, and its construction began in 1974. The task of the reservoir is to cover the needs of local waterworks of the villages of Raniżów and Wola Raniżowska, as well for irrigation and for pond farm in Wilcza Wola. It should be noted that due to small flood capacity of the reservoir, it has little effect on reducing a culmination of a flood wave. It also has a recreational function and is managed by the Polish Angling Association.

The capacity of the reservoir is 3.86 million $\mathrm{m}^{3}$, with an embankment area of 160 ha with a normal damming ordinate $187.50 \mathrm{~m}$ a.s.l. and average depth of $2.45 \mathrm{~m}$. The resultant reservoir is a trough-type tank (Instrukcja, 2011; Tarnawski and Michalec, 2006), and its axis length totals $6.5 \mathrm{~km}$. The overflow section is a complex weir built into the central part of the front of dam body.

The length of the front dam is $420 \mathrm{~m}$, and its crown ordinate is $190.40 \mathrm{~m}$ a.s.1. with a crown width of $6.0 \mathrm{~m}$. The gradient of the slopes is $1: 2.5$, and they are protected from the downstream slope by sod, while from the upstream slope by $15 \mathrm{~cm}$ thick concrete slabs. The total length of all side dams ("A", "B" and "C") totals $3720 \mathrm{~m}$, and the width of their crowns is $3.0 \mathrm{~m}$ on average. The gradient of the slope of the "B" side dam insured with concrete slabs is $1: 3$, and the downstream slope is 1:2.5 (see: Fig. 1). The side dam has three piezometric sections with 3 piezometers in each. Along a) downstream slope - visible girdling ditch

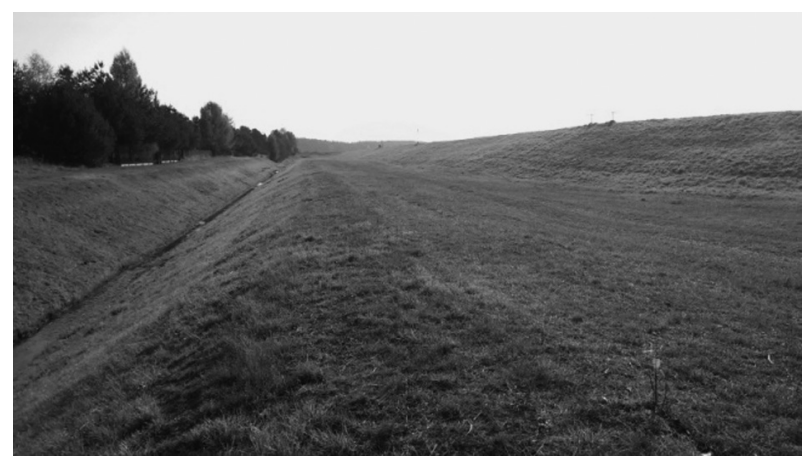

b) upstream slope

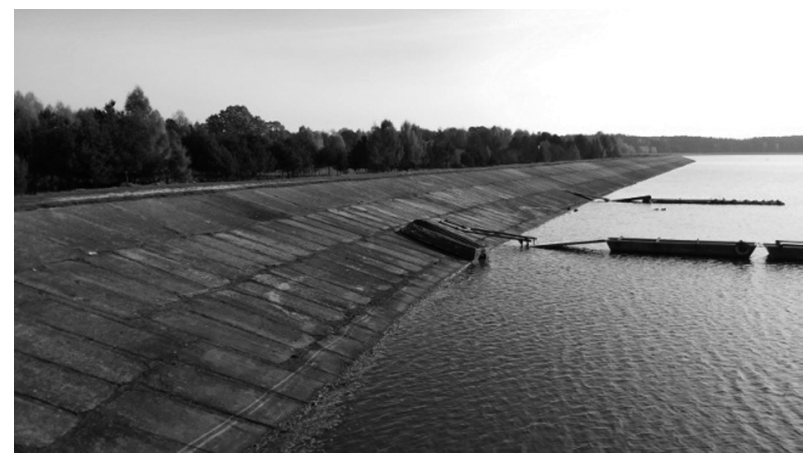

Fig. 1. View on the conditions of the slopes of the "B" dam (photo D. Bembenek) 
the side dam there is a girdling ditch (see: Fig. 1a), whose task is to capture filtration and drain water from a drainage ditch. The gradient of the ditch slopes is $1: 2$, with a $0.5 \mathrm{~m}$ bed width and up to $3.4 \mathrm{~m}$ in depth.

\section{RESEARCH METHODOLOGY}

The fieldwork included geodetic survey of the $300 \mathrm{~m}$ long section of the "B" dam using the Topcon GTS-226 total station and geotechnical exploration of the soil that forms the dam's body in four research cross-sections. In each research cross-section (see: Fig. 2), penetration drilling from the crown of the dam was performed to a depth from 4.9 to $5.3 \mathrm{~m}$ with sampling of separated geotechnical layers to determine granular composition and natural moisture content. Also, trial pits with a depth between 0.9 to $1.1 \mathrm{~m}$ were made on the downstream slope in its upper, middle and lower parts. Every trial pit determined volume density of the soil by the cutter ring method and provided samples to identify granular composition, natural moisture con- tent and permeability coefficient. Based on a geodetic survey, an outline of the dam's body was prepared in the research cross-sections.

Laboratory tests determined the grain-size distribution of soils by sieve and/or hydrometric methods, their natural moisture content by the drying method and the permeability coefficient in the ZWk2 apparatus. The permeability coefficient was applied to samples with close to natural soil moisture content that were compacted in a cylinder to obtain density recorded in field tests. The measurements were made after stabilizing the flow, with a constant hydraulic slope and a vertical direction of water flow, running through the sample "from bottom to top" and "from top to bottom".

The permeability coefficient was also calculated by Hazen, USBSC (so-called "American") and Slichter empirical equations (Pazdro and Kozerski, 1990). The Hazen formula is used to calculate the filtration coefficient of sands and gravels, the relevant diameter of which ranges from 0.1 to $3.0 \mathrm{~mm}$, and the

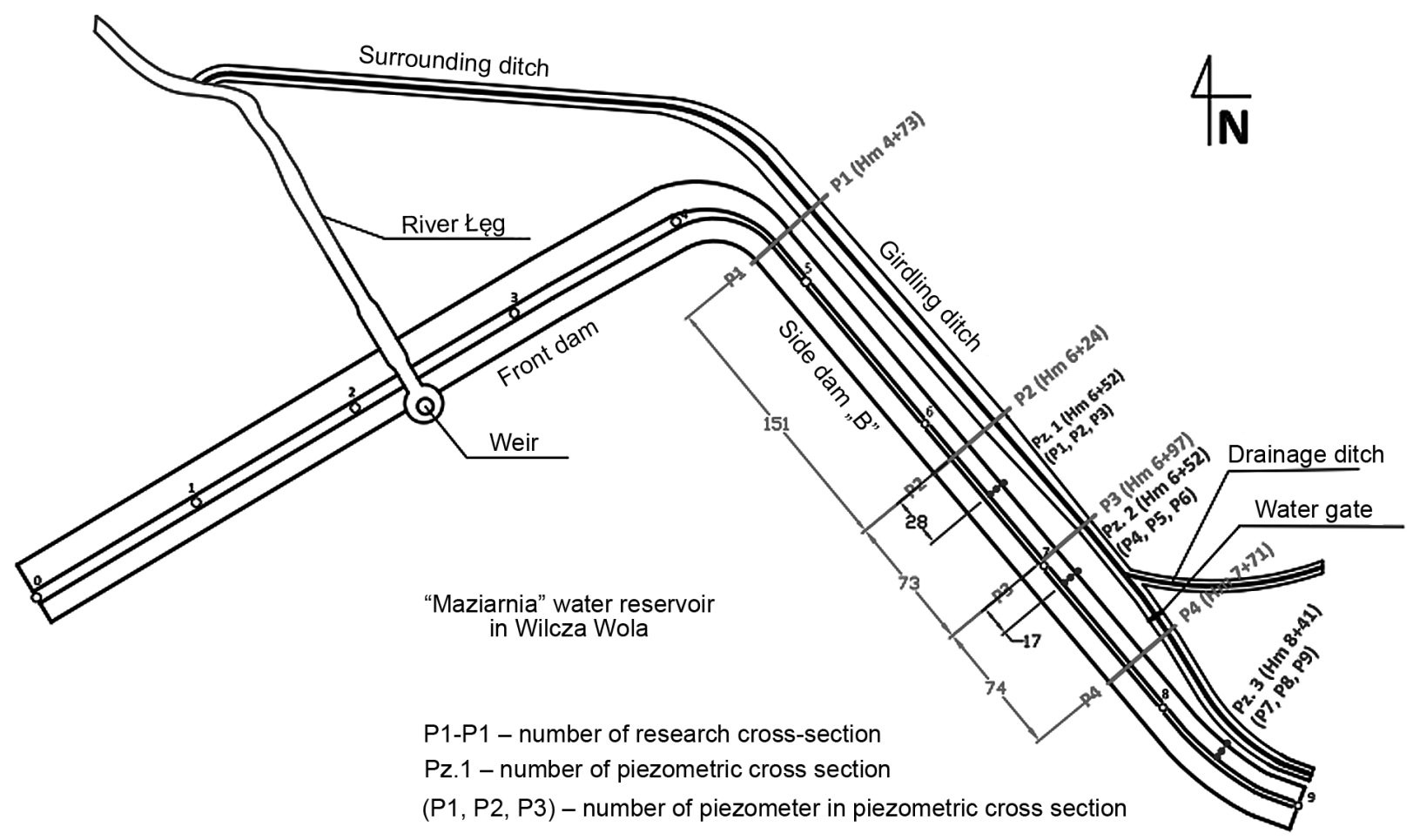

Fig. 2. Location of the research and piezometric cross-sections on the "B" dam of the "Maziarnia" water reservoir in Wilcza Wola 
index of grain variety is $C_{U}<5$. The USBSC "American" equation was developed by Yugoslav and Polish hydrogeologists on the basis of American studies on the dependence of the filtration coefficient on the equivalent diameter $d_{20}$ and can be applied to soils with a diameter $D_{20}$ ranging from 0.01 to $2.0 \mathrm{~mm}$. The Slichter's formula takes into account granulation porosity, temperature and viscosity. Generally, it gives good results in respect to sands and gravels with a reliable diameter between 0.01 and $5.0 \mathrm{~mm}$ (Twardowski and Drożdżak, 2006). Calculations of the permeability coefficient were supposed to indicate differences in the coefficient's value in relation to the values obtained from laboratory tests. In the case of earth hydrotechnical facilities, where geotechnical structures vary significantly in a transverse and longitudinal direction, the correct determination of the permeability coefficient is important for calculating the filtration curve.

Basing on field results and laboratory tests, calculations of both steady and transient filtration were carried out using the finite element method in the GEO5 program. The calculations of steady filtration were made at a height of $186.10 \mathrm{~m}$ a.s.l. of the water table in the reservoir, which was the lowest level recorded in 2015. Whereas, the calculations of transient filtration assumed raising the water table to a height of $187.70 \mathrm{~m}$ a.s.1., which was the highest level recorded in 2015. The height of water in the ditch adjacent to the dam was assumed for the calculations of steady filtration at the level of $0.1 \mathrm{~m}$ (measurement during tests) and $0.4 \mathrm{~m}$ for the calculation of transient filtration. This value was adopted, because of lack of precise information on the filling height of the ditch. The objective for calculating transient filtration was to determine the location of filtration curve and to determine the time required for establishing a filtration flow in consequence of a rapid rise of water table in the reservoir by $1.6 \mathrm{~m}$. Calculations were run after 0.5, 1, 7, 14, 28, 60, 90 and 180 days from the moment of lifting the water table in the reservoir.

Calculations of transient filtration were based on the Richards' continuity equation, assuming no structure frame deformability. In a region of partial saturation the permeability coefficient was defined by the van Genuchten equation (1980):

$$
k_{w}(h)=k_{s} \cdot \frac{\left\{1-\left(\alpha \cdot h^{(n-1)}\right) \cdot\left[1+\left(\alpha \cdot h^{n}\right)^{-m}\right]\right\}^{2}}{\left[(1+\alpha \cdot h)^{n}\right]^{\frac{m}{2}}}
$$

The value of the permeability coefficient is a function of suction pressure, which in turn depends on volumetric moisture content of the soil:

$$
\theta=\theta_{r}+\frac{\left(\theta_{s}-\theta_{r}\right)}{\left[1+(\alpha \cdot h)^{n}\right]^{m}}
$$

given that:

$k_{s} \quad-$ soil permeability coefficient at full saturation $\left[\mathrm{m} \cdot \mathrm{s}^{-1}\right]$,

$k_{\text {in }} \quad-$ soil permeability coefficient at incomplete saturation $\left[\mathrm{m} \cdot \mathrm{s}^{-1}\right]$,

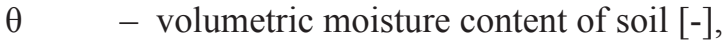

$\theta_{s} \quad-$ volumetric moisture content of soil at full saturation of pore spaces [-],

$\theta_{r} \quad-$ residual volumetric moisture content of the soil [-],

$h \quad-$ suction pressure expressed in $\mathrm{cm}$ of water column $[\mathrm{cm}]$, $\begin{aligned} \alpha, n, m- & \text { constant of }\left(m=1-\frac{1}{n}\right) \text { equation, para- } \\ & \text { meter } \alpha \text { expressed in }\left[\mathrm{cm}^{-1}\right] .\end{aligned}$

The same hydraulic properties in vertical and horizontal directions were adopted for the soil forming body and base of the dam. The parameters of the van Genuchten equation were calculated in the RETC program, and are presented in Tab. 1.

\section{TEST RESULTS}

In the research section P1-1 (Hm 4+73), $4.9 \mathrm{~m}$ in depth, there were medium sands and medium silty sands, and only at a depth of 2.1 to $2.5 \mathrm{~m}$ the interbedded silty clay with sand was found (Bembenek, 2016). Whereas, medium sands and silty clay with sand were located below (Kurzelewski et al., 2010). The moisture content of sands ranged from over $4 \%$ to $14 \%$, and of silty clay with sand reached over $17 \%$ (see: Table 1). The volume density of soil ranged from 1.7 to $1.8 \mathrm{~g} \cdot \mathrm{cm}^{-3}$. The filtration coefficient obtained from laboratory tests 


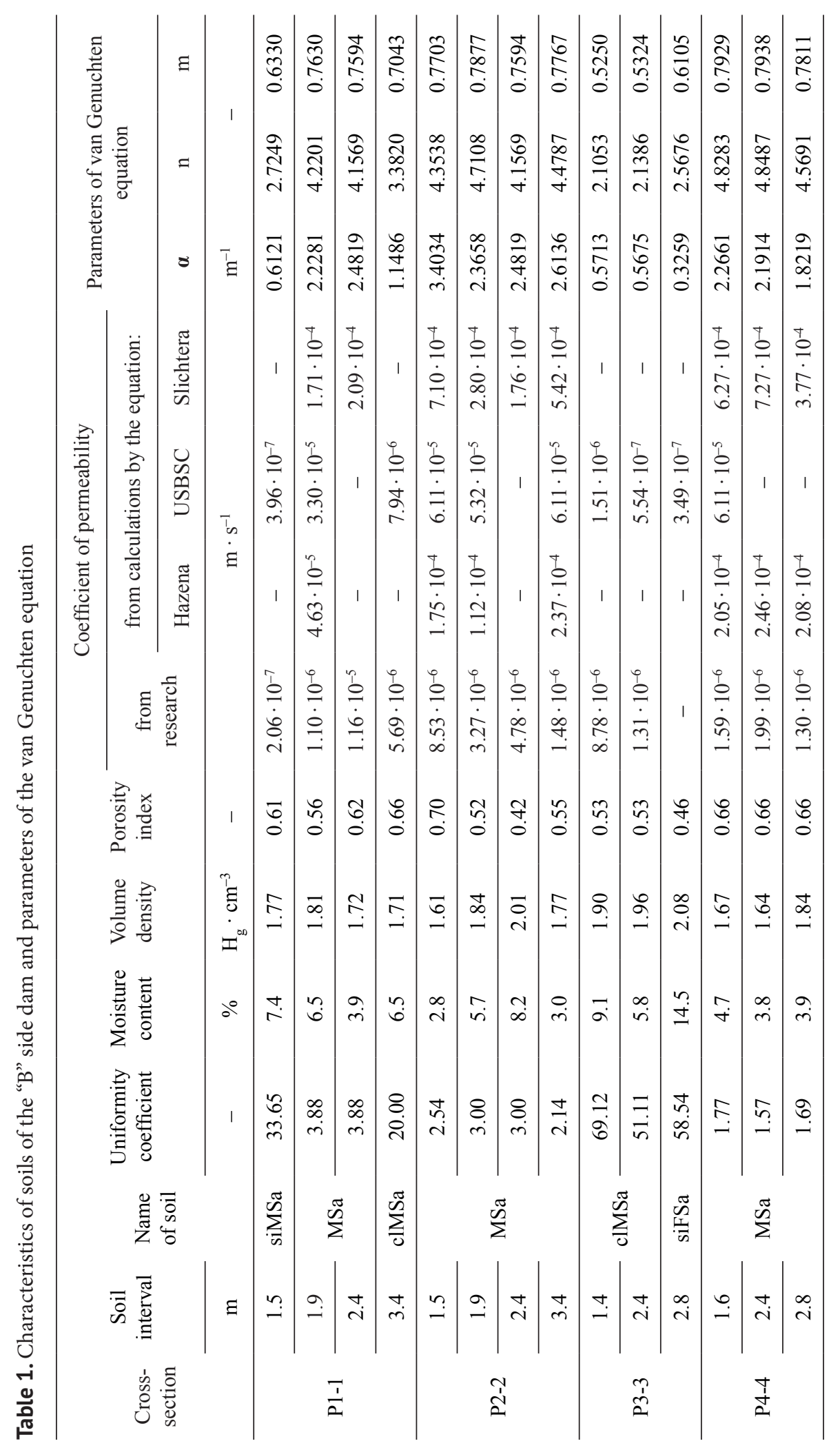


varied from $2.1 \cdot 10^{-7}$ to $1.2 \cdot 10^{-5} \mathrm{~m} \cdot \mathrm{s}^{-1}$, and these values were similar to those calculated with the USBSC equation (from $3.9 \cdot 10^{-7}$ to $3.3 \cdot 10^{-5} \mathrm{~m} \cdot \mathrm{s}^{-1}$ ). In contrast, the Hazen and Slichter equations gave values by 2 orders of magnitude larger and ranged from $4.6 \cdot 10^{-5}$ to $1.7 \cdot 10^{-4} \mathrm{~m} \cdot \mathrm{s}^{-1}$ (Szałucha, 2017).

In the section P2-2 (Hm $6+24), 5.1 \mathrm{~m}$ in depth, there were medium sands with moisture content from $7 \%$ to $17 \%$ and specific gravity between 1.6 and $2.0 \mathrm{~g} \cdot \mathrm{cm}^{-3}$. The permeability coefficient for medium sands averaged in laboratory tests $4.6 \cdot 10^{-3} \mathrm{~m} \cdot \mathrm{s}^{-1}$. While the values calculated with the USBSC equation were by one order of magnitude larger, and with the Hazen and Slichter equations by three orders larger.

In the section P3-3 (Hm 6 + 97), $5.3 \mathrm{~m}$ in depth, there were medium silty and fine sands. The moisture content of sands ranged from over $6 \%$ to $15 \%$, and volume density - from 1.9 to $2.1 \mathrm{~g} \cdot \mathrm{cm}^{-3}$. The filtration coefficient for medium silty sands averaged $5.0 \cdot 10^{-6} \mathrm{~m} \cdot \mathrm{s}^{-1}$, and after calculating with the USBS equation it gave results similar or just by an order of magnitude smaller.

The section P4-4 (Hm $7+71)$ to $5.0 \mathrm{~m}$ in depth was dominated by medium sands with interbedding of medium silty sands, and silty clay with sand was the most common below that level (Kurzelewski et al., 2010). The moisture content of sands was from $3 \%$ to $9 \%$. The volume density ranged from 1.64 to $1.69 \mathrm{~g} \cdot \mathrm{cm}^{-3}$, and at a depth of about $3.0 \mathrm{~m}-$ from 1.80 to $1.84 \mathrm{~g} \cdot \mathrm{cm}^{-3}$. The filtration coefficient for medium sands averaged $1.7 \cdot 10^{-6} \mathrm{~m} \cdot \mathrm{s}^{-1}$. While calculations based on the USBS equation were larger by an order of magnitude, and these using the Hazen and Slichter equation were larger by two orders of magnitude on average.

It was assumed for calculating steady and transient filtration that medium sands rest at the base, in the catchment and under the ditch of the dam, which was in line with Kurzelewski et al. (2010).

\section{RESULTS OF FILTRATION CALCULATIONS}

In result of rising or lowering of water table in the reservoir related to flood water flow, transient filtration will be operating in the dam body. However, if the water level maintains for a relatively long period, the conditions of filtration flow will stabilize enabling steady filtration. Filtration at high water levels may lead to waterlogging of the dam's and catchment's soil, which in turn can cause problems with the stability of the downstream slope. Running filtration calculations with regard to steady and transient flow conditions allows deciding to what extent modernization works should be realised, e.g. sealing a dam. These calculations also allow specifying, after which period seepage will occur on a downstream slope, or just like in this case in a girdling ditch. The calculations in the conditions of steady filtration also determine the location of water table inside the dam body, the limit flow curve, and thus the filtration curve, which also provides information on saturation limits of dam soil (Rembeza, 2007). It should be noted that locating the filtration curve is particularly important in winter. The curve should be distanced from the downstream slope or bench by a depth of ground freezing. If this condition is not met, depression curve can be dammed due to an obstacle in the form of frozen ground, as well as heaving processes related to freezing and thawing cycles. It may contribute to the deterioration of the building's stability (Bednarczyk et al., 2009; Chalfen and Kamińska, 2011).

Calculations of transient flow were carried out in few phases. The first was to determine the initial conditions, which corresponded to the flow fixed at an assumed water level in the reservoir, in this case -186.10 m a.s.l. (see: Fig. 3). Steady filtration calculations showed a similar range of pore pressures obtained in all research cross-sections. It should be noted that the course of the seepage line passed well below the base of the downstream slope.

In subsequent phases, calculations were carried out in transient filtration conditions in a period between 0.5 to 180 days after lifting water in the reservoir by $1.60 \mathrm{~m}$. Calculations indicated changes in time of the saturation limit and thus of the water flow volume. In Fig. 4, as an example for the P2-2 cross-section, the saturation limit is shown under transient filtration conditions. As in previous calculations, the course of the seepage line after 180 days was also below the base of the downstream slope. So, it can be said for sure that the water seepage through the body and base of the dam does not threaten the safety of the structure. It should be added that the sealing of the reservoir bed from main and lateral sides of the dam with Estrofol 
a) cross-section P1-1

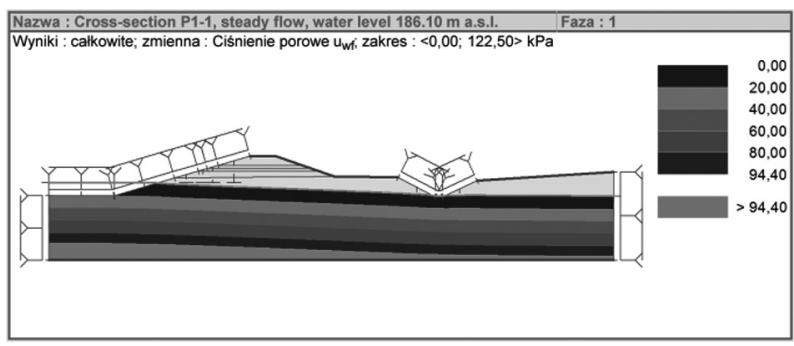

c) cross-section P3-3

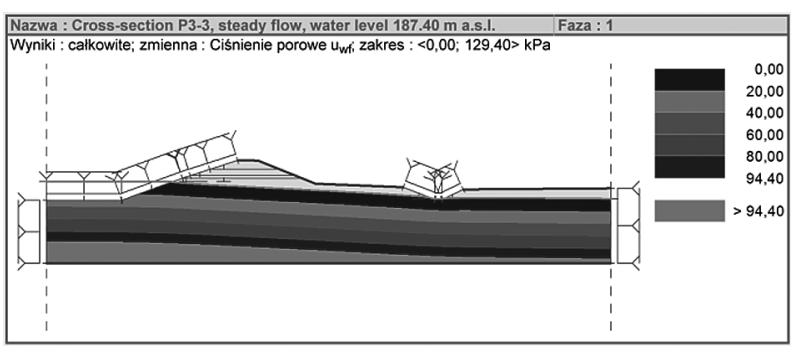

b) cross-section P2-2

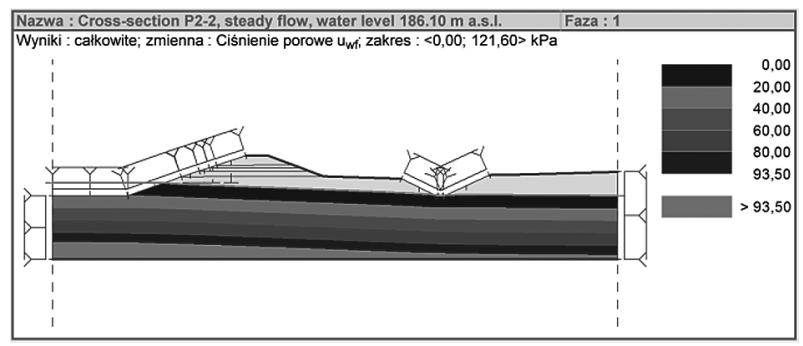

d) cross-section P4-4

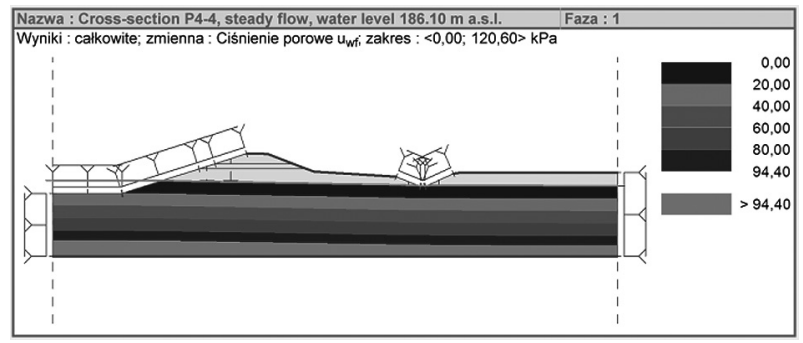

Fig. 3. The course of the seepage line with changes in pore pressure in steady filtration conditions determined from calculations in the GEO5 software for a water table with a height of $187.40 \mathrm{~m}$ a.s.l.

foil (Instrukcja, 2011) and the reinforcement of the upstream slope with split concrete slabs were omitted in calculations. Although not leaktight, these slabs are in good technical condition and can be expected to limit the water filtration. Therefore, it can be assumed that the flow rate will be lower, and so the filtration curve will be below a curve calculated by the finite element method.

Calculations indicate relatively large differences in the seepage line height between steady and transient filtration. On the downstream slope at its base, these values ranged from $0.58 \mathrm{~m}$ in the P3-3 cross-section to $1.00 \mathrm{~m}$ in the $\mathrm{P} 2-2$ section. These changes affirm the observations of piezometric water held in the piezometric cross-sections on the downstream slope. The Fig. 5 shows changes in the height of the piezometric water table recorded in 2015. The water level in the reservoir shifted by $1.60 \mathrm{~m}$, resulting in water table fluctuations in piezometers that ranged from $0.21 \mathrm{~m}$ (P9 piezometer - Fig. 1) to $0.59 \mathrm{~m}$ (P6 piezometer Fig. 1). Only in the P4 piezometer these fluctuations amounted to $0.15 \mathrm{~m}$. This piezometer is probably clogged, because registered water level changes do not show a clear relation to fluctuations of the water table in the reservoir, as was the case with other piezometers.

Comparing the course of the filtration curve determined by the finite element method and measurements of the piezometric water height (see: Fig. 6) can indicate a significant coincidence of obtained results. Raising the water table level in the reservoir also lifted the filtration curve - for example, by $1.0 \mathrm{~m}$ in the research section P2-2 at the base of the downstream slope, and in the piezometric section Pz.3 only by $0.34 \mathrm{~m}$. The numerical calculations, taking into account the depth of freezing, which for the Podkarpackie Voivodeship (PN-B-0320: 1981) is $1.0 \mathrm{~m}$, indicated a height reserve of $0.95 \mathrm{~m}$, and measurements in piezometers a reserve of about $1.20 \mathrm{~m}$ at the base of the downstream slope.

Calculations of the volume of the water flow through the body and base of dam demonstrate that the rate of water outflow to the body from the reservoir's side and the rate of water outflow from the reservoir to the ditch diverged in calculations of transient filtration. This may indicate the need to extend 
the time required for determining the flow rate. It should be noted, however, that the values of differences are small, and generally after about 90 days for P1-1, P2-2 and P3-3 and 180 for P4-4 the flow did stabilize (see: Fig. 7). Therefore, 90 days can be taken as the time required for stabilizing the steady flow conditions after raising water in the reservoir.

\section{a) $\mathrm{t}=1$ day}

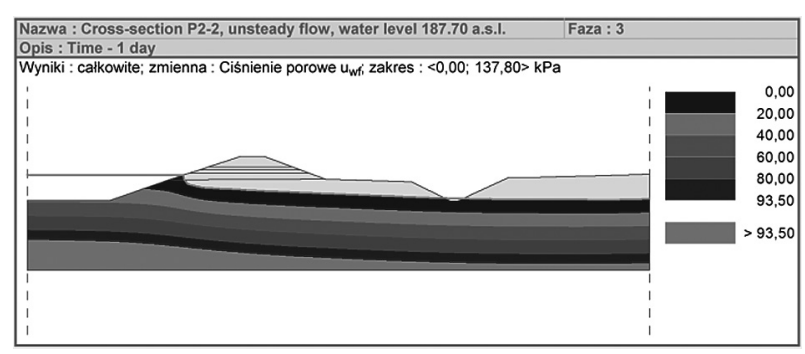

c) $\mathrm{t}=28$ days

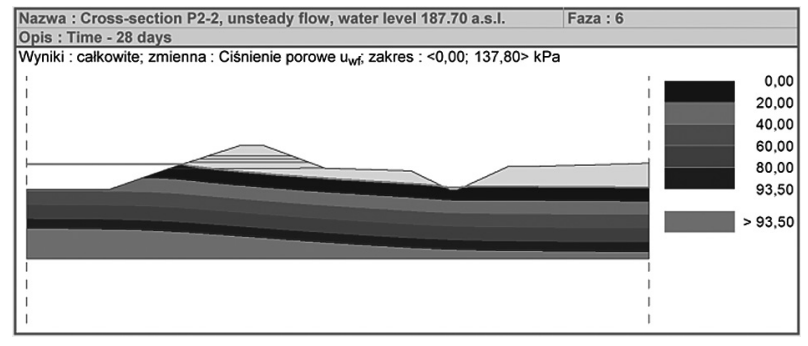

e) $\mathrm{t}=90$ days

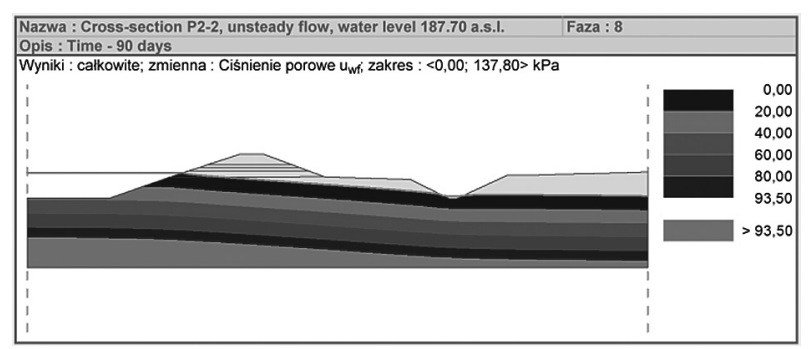

The observations of fluctuations of the water table in the reservoir indicate that such long period of high levels as a result of, for example, flood wave (see: Fig. 5) crossing through the structure, were not recorded. Thus, there is no risk of deterioration of working conditions of the facility due to increased filtration through the dam body.

b) $\mathrm{t}=7$ days

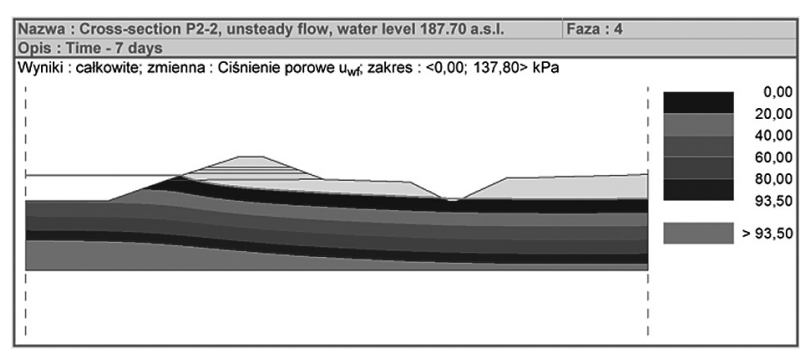

d) $t=60$ days

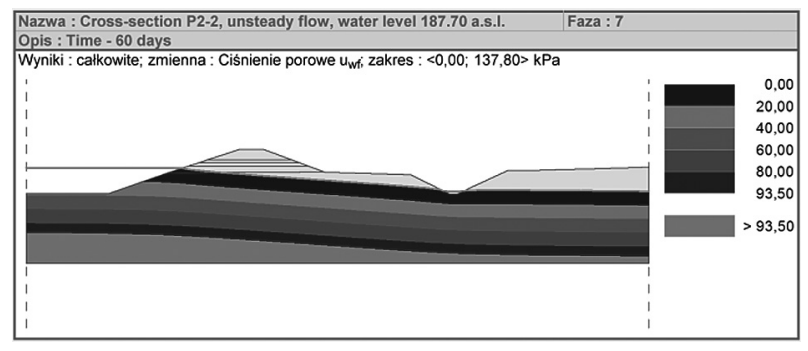

f) $\mathrm{t}=180$ days

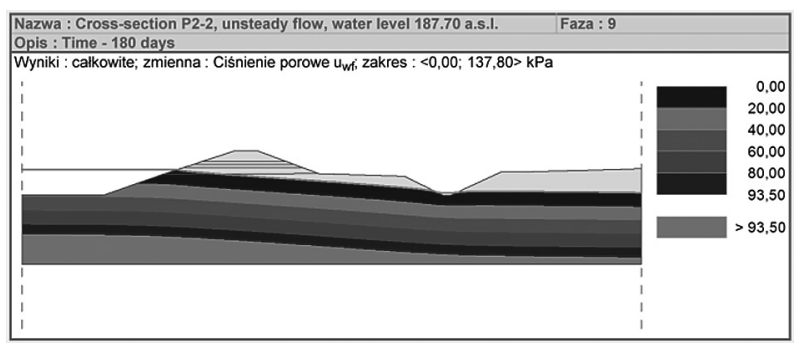

Fig. 4. The course of the saturation limit (seepage line) with changes in pore pressure under transient filtration conditions in the section P2-2 from the GEO5 software 
a) piezometric cross-section Pz. 1

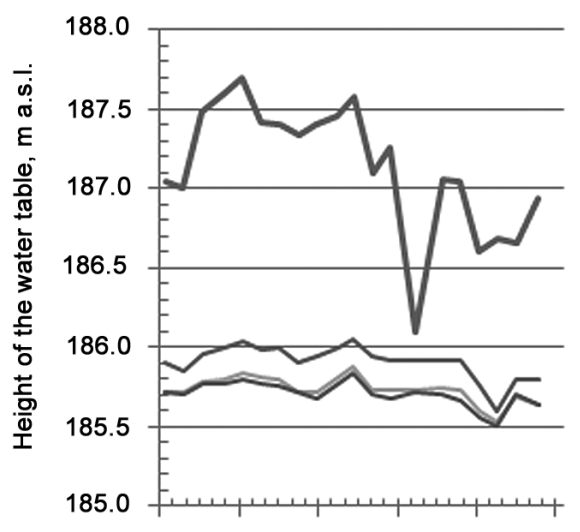

b) piezometric cross-section Pz.2

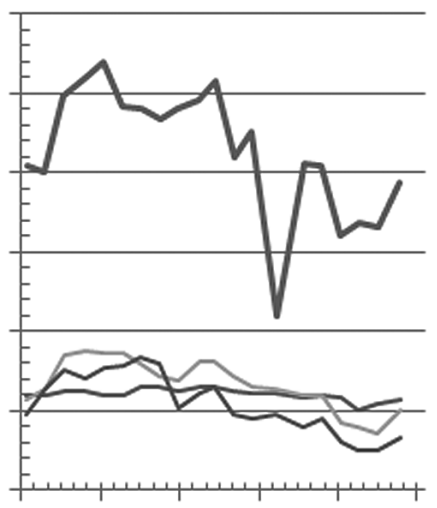

c) piezometric cross-section Pz.3

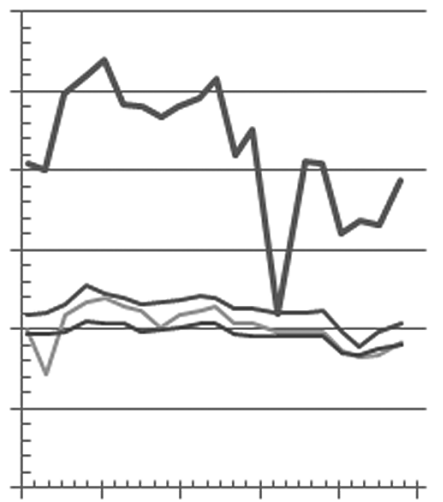

1 jan 2 mar 1 may 30 jun 29 aug 28 oct

$$
-\mathrm{P} 1-\mathrm{P} 2-\mathrm{P} 3 \quad \mathrm{P} 4-\mathrm{P} 5-\mathrm{P} 6
$$$$
-\mathrm{P} 7-\mathrm{P} 8-\mathrm{P} 9
$$

Fig. 5. Changes in the height of the water table in the reservoir and in piezometers in 2015

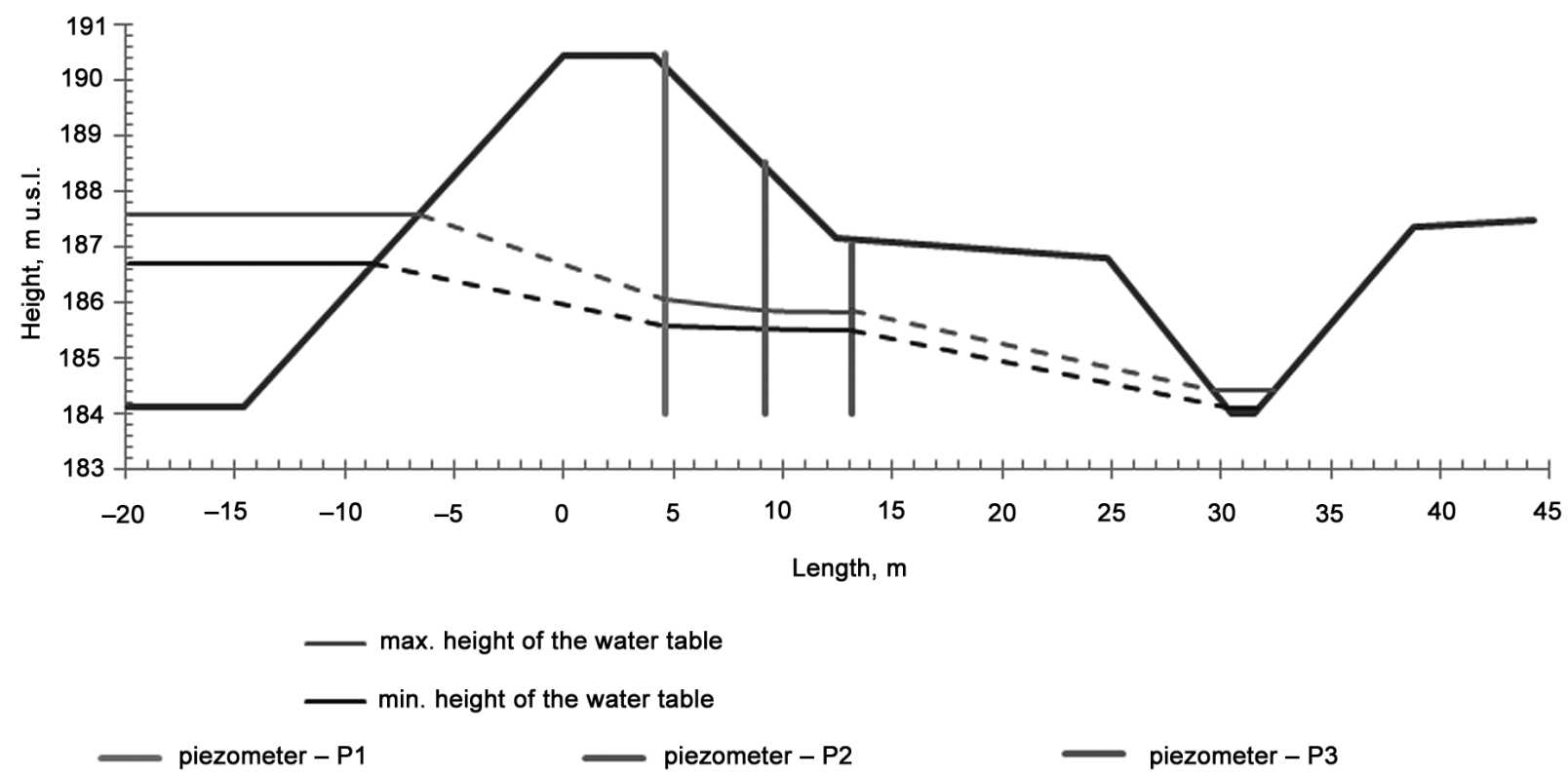

Fig. 6. Changes in the water table level in the dam body based on water readings in piezometres of the Pz.1 piezometric cross-section (the hypothetical course of the filtration curve is shown in broken lines) 
a) the P1-1 cross-section

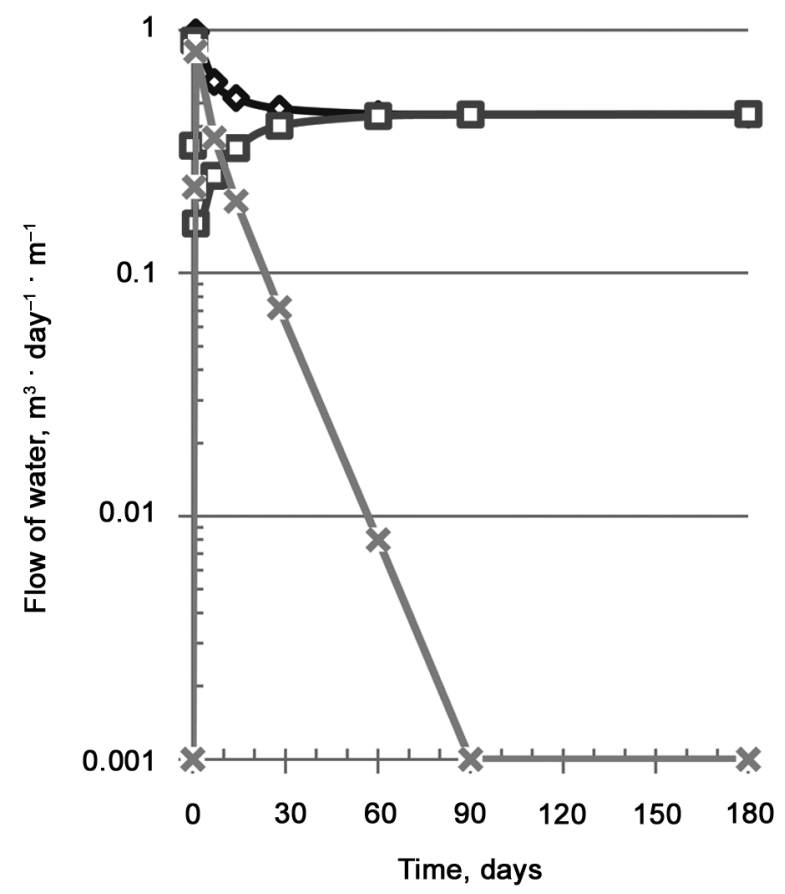

c) the P3-3 cross-section

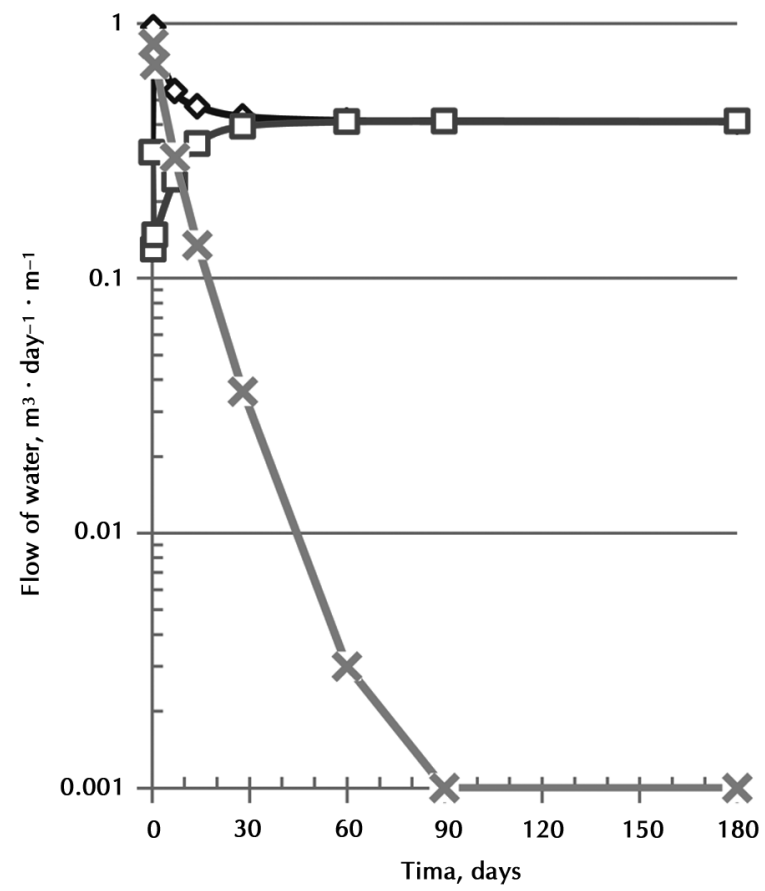

b) the P2-2 cross-section

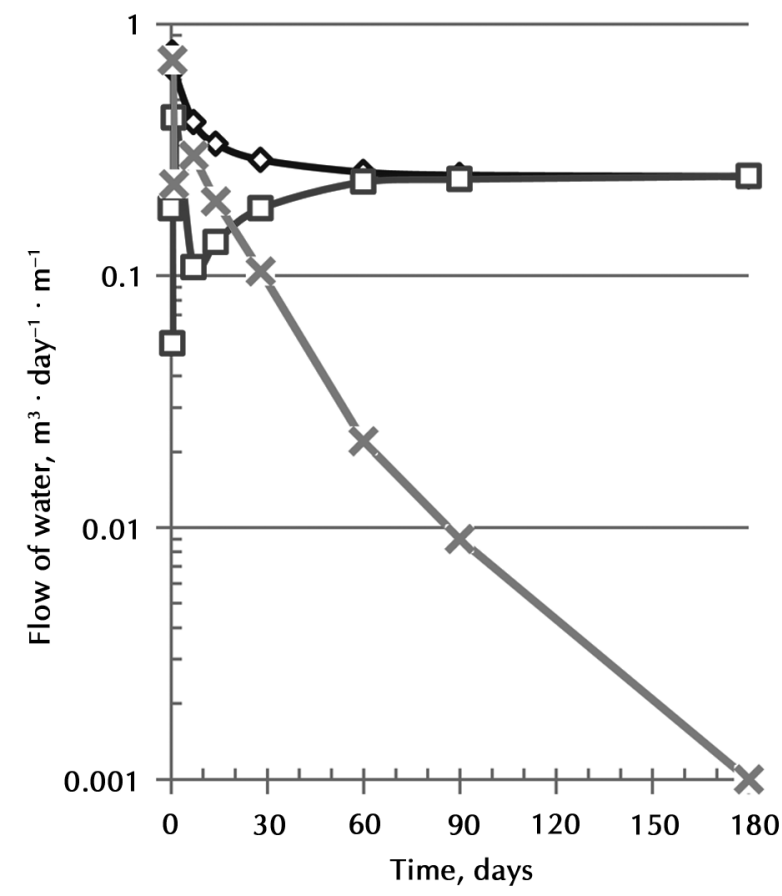

d) the P4-4 cross-section

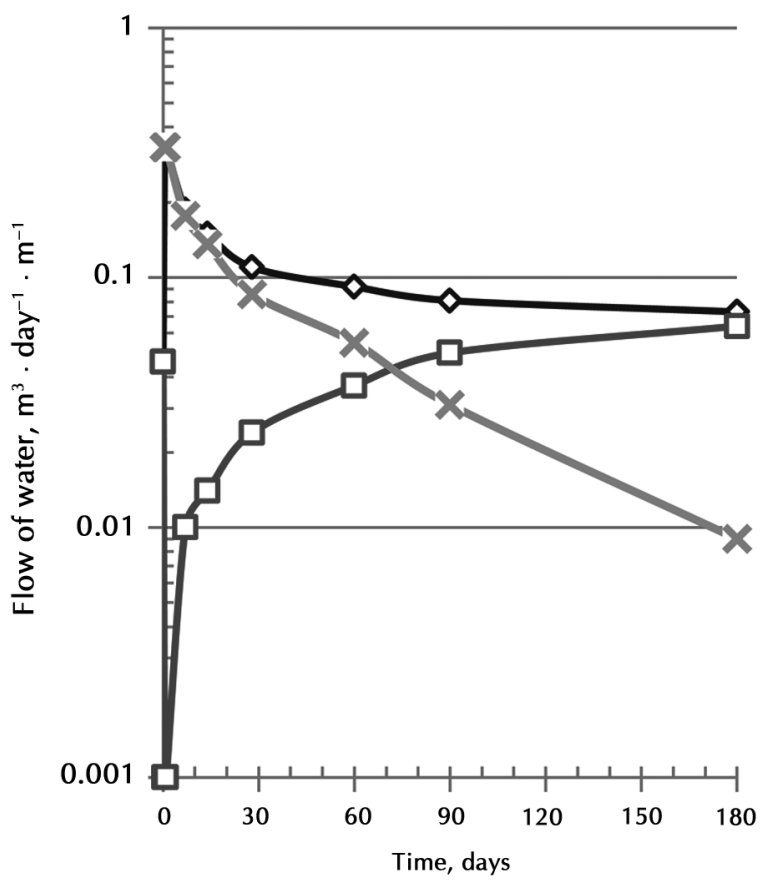

Fig. 7. The relation between the water flow through the embankment dam to time from calculations of unsteady filtration in the Geo5 


\section{SUMMARY}

In conclusion, it is clear that in the body of the lateral dam " $\mathrm{B}$ " of the Maziarnia water reservoir is dominated by non-cohesive soils, mainly medium sands. Medium silty clays with sand occurred to a lesser extent. Research on the filtration coefficient indicates that soils with weak permeability prevail in the dam body. The values of this parameter obtained from calculations with empirical equations are from one to several orders larger than those from laboratory tests. The USBS equation had the best correspondence of the filtration coefficient values calculated and obtained from the tests. Therefore, it is proposed that filtration calculations should be carried out using the coefficient of permeability determined from research done at least in laboratory.

The flow calculations showed that the course of the filtration curve does not compromise the safety of the lateral dam "B". Its location at the maximum level of the water table in the reservoir in 2015 corresponded to a depth of ground freezing. This is confirmed by numerical calculations, as well as observations of the water table in piezometres.

The computational method used allowed to obtain a high correspondence of the filtration curve with water observations in piezometers. It was estimated that the time for stabilizing the steady flow after raising the water table in the reservoir by $1.60 \mathrm{~m}$ equals 90 days, a much longer period than a flood wave.

The next stage of the research will be to assess the stability of the considered structure, while preserving changes in the flow and filtration curve in the dam body as a result of fluctuations in the water table in the reservoir.

\section{REFERENCES}

Bednarczyk, S., Bolt, A., Mackiewicz, S. (2009). Stateczność oraz bezpieczeństwo jazów i zapór. Gdańsk: Wydawnictwo Politechniki Gdańskiej.

Bembenek, D. (2016). Ocena stanu technicznego zapory ziemnej zbiornika wodnego Maziarnia. Praca magisterska wykonana w Katedrze Inżynierii Wodnej i Geotechniki Uniwersytetu Rolniczego w Krakowie, maszynopis.

Borys, M. (2007). Określenie parametrów tarcia na styku geosyntetyków i gruntów pod kątem budowy ekranów przeciwfiltracyjnych w wałach przeciwpowodziowych.
III Konferencja Naukowa „Woda-Środowisko-Obszary wiejskie", IMUZ Falenty, 41-42.

Borys, M., Mosiej, K. (2005). Wytyczne wykonywania ocen stanu technicznego i bezpieczeństwa wałów przeciwpowodziowych. Wydawnictwo IMUZ, Falenty.

Chalfen, M., Dąbrowska, J., Molski, T. 2008. Filtracja wody przez nowy i modernizowany wał przeciwpowodziowy Odry w Kozanowie. Infrastruktura i Ekologia Terenów Wiejskich, 7, 31-44.

Chalfen, M., Kamińska, J. (2011). Wpływ niedokładności określenia współczynnika filtracji elementów uszczelniających na warunki przepływu wody przez wały przeciwpowodziowe. Acta Scientarum Polonorum, Seria Architectura, 10 (1), 5-17.

Depczyński, W., Szamowski, A. (1999). Budowle i zbiorniki wodne. Warszawa: Oficyna Wydawnicza Politechniki Warszawskiej.

Dz.U. z 1994 r., nr 89, poz. 414. Prawo budowlane. Ustawa z dnia 7 lipca 1994 r. z późniejszymi zmianami.

Dz.U. z 2007 r., nr 86, poz. 579. Rozporządzenie Ministra Środowiska z dnia 20 kwietnia 2007 r. w sprawie warunków technicznych, jakim powinny odpowiadać budowle hydrotechniczne i ich usytuowanie.

Instrukcja 2011. Instrukcja gospodarowania wodą dla zbiornika w Wilczej Woli. Zakład Usług Geodezyjno-Projektowych, Marek Gamracy, Rzeszów.

Kledyński, Z. (2011). Monitoring i diagnostyka budowli hydrotechnicznych. Cz. 2. Nowoczesne Budownictwo Inżynieryjne, 3(36), 36-38.

Kurzelewski, J., Mirecki, J., Kowalski, M. (2010). Ocena stanu technicznego zbiornika wodnego w Wilczej Woli. GEOTEKO Projekty i Konsultacje Geotechniczne, Sp. z o.o., maszynopis.

Pazdro, Z., Kozerski, B. (1990). Hydrogeologia ogólna. Warszawa: Wydawnictwa Geologiczne,

PN-B-03020:1981. Grunty budowlane. Posadowienie bezpośrednie budowli. Obliczenia statyczne i projektowanie. Warszawa: Polski Komitet Normalizacyjny.

Rembeza, L. (2007). Nieustalony przepływ filtracyjny przez wał przeciwpowodziowy z uszczelnieniami, Gospodarka Wodna, 9, 380-382.

Szałucha, Ł. (2017). Ocena stanu zagęszczenia i warunków filtracji przez zaporę ziemną zbiornika wodnego „Maziarnia”. Praca magisterska wykonana w Katedrze Inżynierii Wodnej i Geotechniki Uniwersytetu Rolniczego w Krakowie, maszynopis.

Tarnawski, M., Michalec, B. (2006). Charakterystyka ilościowa i jakościowa osadów dennych zbiornika wodnego w Wilczej Woli. Infrastruktura i Ekologia Terenów Wiejskich, 3, 31-43. 
Twardowski, K., Drożdżak, R. (2006). Pośrednie metody oceny właściwości filtracyjnych gruntów. Wiertnictwo Nafta Gaz, 23/1, 477-786.

van Genuchten, M.T. (1980). A closed form equation for predicting the hydraulic conductivity of unsaturated soils. Soil Science Society American Journal, 44, 892-898.
Wiłun, Z. (2001). Zarys geotechniki. Warszawa: Wydawnictwa Komunikacji i Łączności.

Zawisza, E., Klimek, K. (2016). Wodoprzepuszczalność gruntów skarpy abrazyjnej zbiornika Czorsztyn-Niedzica. Acta Scientarum Polonorum Formatio Circumiectus 15(4), 395-407

\section{ANALIZA PROCESÓW FILTRACYJNYCH PRZEZ ZIEMNĄ BUDOWLĄ HYDROTECHNICZNĄ}

\section{ABSTRAKT}

\section{Cel pracy}

W pracy przedstawiono obliczenia filtracji przez zaporę boczną zbiornika wodnego „Maziarnia” w Wilczej Woli w województwie podkarpackim.

\section{Materiał i metody}

W wytypowanych przekrojach, w oparciu o wiercenia penetracyjne i wkopy badawcze rozpoznano budowę geotechniczną korpusu zapory oraz pobrano próbki gruntów do badań laboratoryjnych. Wyniki badań właściwości fizycznych i współczynnika filtracji gruntów wykorzystano do obliczeń filtracji ustalonej i nieustalonej przez zaporę metodą elementów skończonych w programie GEO5.

\section{Wyniki i wnioski}

Analiza wyników badań wykazała istotne różnice pomiędzy wartościami współczynnika filtracji uzyskanymi z badań laboratoryjnych i obliczonymi wzorami empirycznymi. Obliczenia numeryczne położenia krzywej filtracji przez zaporę wykazały stosunkowo dobrą zgodność z krzywą filtracji z pomiarów piezometrycznych.

Słowa kluczowe: współczynnik filtracji, metoda elementów skończonych, zapora ziemna 